$\begin{array}{rr}\text { Primljen / Received: } \quad \text { 4.3.2016. } \\ \text { Ispravljen / Corrected: } & \text { 28.6.2017. } \\ \text { Prihvaćen / Accepted: } & \text { 15.3.2018. }\end{array}$

Dostupno online / Available online: 10.5.2019.

\title{
Analyses of cement mortars containing reclaimed asphalt pavement by using DTA/TG and FTIR
}

Authors:

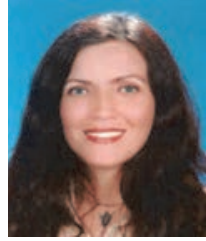

Assoc.Prof. Özlem Çelik Sola, PhD. CE Istanbul University, Turkey Faculty of Civil Engineering celik@istanbul.edu.tr

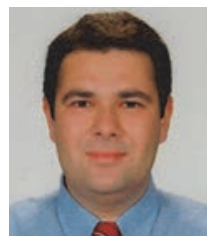

Assist.Prof. Cemil Ozyazgan, PhD. CE Affairs - Istanbul University, Turkey Department of Construction and Technical Affairs cemil.ozyazgan@kirklareli.edu.tr
Znanstveni rad - Prethodno priopćenje

Ozlem Celik Sola, Cemil Ozyazgan

\section{Odredivanje svojstava cementnog morta s dodatkom kolničkog asfalta koristeći DTA/TG i FTIR analizu}

Reciklirani asfaltni kolnik (RAP) koristi se u istraživanju kao reciklirani materijal za proizvodnju cementnog kompozita. Za proizvodnju uzoraka u cement je dodano 5 \%, 10 \% i $15 \%$ RAP-a. TG/DTA analiza, izvedena nakon određivanja savojne čvrstoće, pokazala je da se minimalan gubitak mase uzorka javio u uzorcima s $5 \%$ RAP-a pri kontroliranim uvjetima. Najveći gubitak mase iznosio je 11,8 \% a druga najviša vrijednost iznosila je $8,2 \%$ za uzorke koji imaju $15 \%$ aditiva C $\mathrm{i}$ koji su se njegovali pomoću otopine $\mathrm{MgSO}_{4}$.

Ključne riječi:

reciklirani asfalt (RAP), DTA/TG, FTIR, čvrstoća

Forschungsbericht

Ozlem Celik Sola, Cemil Ozyazgan

Bestimmung der Eigenschaften von Zementmörtel mit Zusatz von Fahrbahnasphalt mittels der DTA/TG und FTIR Analyse

Der recycelte Fahrbahnasphalt (RAP) wird bei der Untersuchung als recyceltes Material für die Produktion von Zementverbund verwendet. Für die Produktion von Zementproben wurden $5 \%, 10 \%$ und $15 \%$ RAP hinzugefügt. Die TG/DTA Analyse, ausgeführt nach der Bestimmung der Biegefestigkeit durchgeführt wurde, zeigte an, dass unter kontrollierten Bedingungen ein minimaler Masseverlust bei den Proben mit 5 \% RAP auftrat. Der größte Masseverlust betrug 11,8\%, und der zweithöchste Wert betrug 8,2 \% bei den Proben, welche den Zusatz C in Höhe von 15 \% hatten, und die mithilfe der Lösung $\mathrm{MgSO}_{4}$ gepflegt wurden.

Schlüsselwörter:

recycelter Asphalt (RAP), DTA/TG, FTIR, Beständigkeit 


\section{Introduction}

Many countries in the world use RAP as recycled material in road construction. In Europe, asphalt mixtures containing less than $20 \%$ of recycled material can be labelled as "all virgin". Asphalt is the most recycled material in the U.S, having a re-use rate of $99 \%$. However, on an average, only $10-20 \%$ of RAP is used in mixture design [1]. This suggests that the amount of RAP in mixtures can be increased significantly, if the interaction between the RAP material and virgin material is conceived better and thus improved [2].

During hydration of the ordinary Portland cement (OPC) concrete, the compounds present in cement, such as $\mathrm{C}_{3} \mathrm{~S}$ and $\mathrm{C}_{2} \mathrm{~S}$, react with water in order to form calcium silicate hydrates $(\mathrm{C}-\mathrm{S}-\mathrm{H})$ and calcium hydroxide, $\mathrm{Ca}(\mathrm{OH})$. The thermogravimetric analysis (TG/DTA) could be employed to determine the degree of pozzolanic reaction and hydration of blended cement pastes [3] and to estimate $\mathrm{Ca}(\mathrm{OH})_{2}$ and calcium hydrates contents [47]. The DTA curve presents a sharp endotherm between 450 and $520 \mathrm{C}$ due to decomposition of $\mathrm{Ca}(\mathrm{OH})_{2}$ occurring during the hydration. Hussain et al. [8] conducted TG/DTA analysis on the fly ash blended cement pastes after hydration for 180 days and reported that $\mathrm{Ca}(\mathrm{OH})_{2}$ content was reduced by $53 \%$ compared to the ordinary Portland cement paste. Feldman et al. [9] conducted TG/DTA analysis on fly ash blended and Portland cement pastes and investigated the effect of the $w / c$ ratio and hydration time on the $\mathrm{Ca}(\mathrm{OH})_{2}$ content variation [9]. The study revealed that $\mathrm{Ca}(\mathrm{OH})_{2}$ decreased with w/c ratio and hydration time for the blended cement paste, such as fly ash, whereas an increase was noted in the experiments involving Portland cement. Using the molybdite method, Hubbert et al. determined that the $\mathrm{C}-\mathrm{S}-\mathrm{H}$ phase is implicitly related to hydration time for calculating unreactive $\mathrm{SiO}_{2}$ in the hydrated cement powder [10]. The study revealed that in blended cement pastes the unreactive $\mathrm{SiO}_{2}$ ranges from 6 to $9 \%$, while the value was $15 \%$ in Portland cement. Accordingly, lower unreactive $\mathrm{SiO}_{2}$ indicates greater $\mathrm{C}-\mathrm{S}-\mathrm{H}$ formation in the blended cement matrix.

The characteristic property of capillary-porous materials, including cement matrix composites, is their ability to absorb and transport moisture, in their liquid and gaseous phases. Capillarity (capillary absorption) is the measurement of the rate at which water is absorbed by a porous solid. The absorption rate is influenced by the quantity, size, and connection of pores. In literature, capillarity is also known and referred to as sorptivity or rising damp.

Several studies have been conducted over the last two decades to evaluate the effect of RAP on the performance of hot mix asphalt (HMA) in road pavement construction [11-17]. Previous studies have mainly focused on the characterization of RAPcontaining asphalt mixtures. However, none of these studies attempted to observe the effect of RAP powder as an additive for concrete technology. In this study, RAP implies removed and /or reprocessed pavement materials containing asphalt. These materials are produced when asphalt pavements are removed for reconstruction, resurfacing, or for accessing buried utilities. Properly crushed and screened RAP consisting of highquality, well-graded aggregates coated by bitumen was used to decrease the quantity of capillary water [18]. The FTIR and thermogravimetric analysis (TG/DTA) was used, in addition to capillarity tests, for determining the phase compositions and mass losses of samples.

\section{Experimental procedure}

\subsection{Materials used in this study}

CEM II/AL-LL 42.5 N Portland cement (PC) conforming with ASTM C150 was used in this study. The RAP mixture was obtained by the company Isfalt. For the production of cement composite, the RAP mixture was filtered through sieves of different size intervals: $0.425-2 \mathrm{~mm}$ (group A), 0.18-0.425 mm (group B), and 0.075-0.18 mm (group C). The standard Rilem sand, with the unit weight of $1.352 \mathrm{~kg} / \mathrm{m}^{3}$ and the specific gravity of 2.563 , was used to prepare the cement mixtures.

\subsection{Mixture preparation and test methods}

A sand/cement/water ratio of 3/1/0.5 was utilized for all cement mixtures. According to this ratio, $1350 \mathrm{~g}$ of standard Rilem sand, $450 \mathrm{~g}$ of cement- RAP, and $225 \mathrm{~g}$ of water, were mixed to obtain the mixtures. According to this mixing procedure, $5 \%$, $10 \%$, and $15 \%$ of RAP was needed in the cement mass to reach the optimum replacement value in the mixtures by means of specimens measuring $4 \times 4 \times 16 \mathrm{~cm}$.

A pycnometer (AccuPyc 1330 model) test device was used to determine density of cement mixtures. According to this test method, the density of the solid is obtained by measuring displacement of gas passing through the solid sample. In this study, helium was employed for that purpose. The Blaine test based on the air permeability method was conducted in accordance with ASTM C204-11. The specific gravity of the samples had to be measured prior to the Blaine test. The time a constant amount of air needs to pass through the compacted sample bed at constant porosity was recorded and dimensions were then measured. Finally, the specific surface calculation is performed to determine the Blaine surface area. Physical properties of cement samples, including the spread and Blaine values, are given in Table 1. All DTA-TG analyses for this study were conducted using a Seiko Ekstar 6000 TG/DTA 6300 device. The air atmosphere (gas flow rate: $100 \mathrm{ml} / \mathrm{min}$ ) was used in the experiments. A $20 \mathrm{mg}$ sample was heated from 25 to $1000^{\circ} \mathrm{C}$, and a heating rate of $10^{\circ} \mathrm{C} / \mathrm{min}$ was used for every sample. All FTIR analyses were performed with a Spectrum One model, Fourier- transform infrared spectroscopy device (Perkin Elmer Precisely brand). The FTIR spectra of the products were measured in the region of 4000 to $400 \mathrm{~cm}^{-1}$ using $\mathrm{KBr}$ pellets measuring $13 \mathrm{~mm}$ in radius and a $200 \mathrm{mg}$ in weight, $\mathrm{KBr}: 1.99$ in $(\% w)$. 
Table 1. Chemical and physical properties of cement mixtures used in testing

\begin{tabular}{|c|c|c|c|c|c|c|c|c|c|c|}
\hline \multicolumn{11}{|c|}{ Chemical analysis } \\
\hline Components & Cement [\%] & $\% 5 A$ & $\% 5 B$ & $\% 5 \mathrm{C}$ & $\% 10 A$ & $\% 10 \mathrm{~B}$ & $\% 10 C$ & $\% 15 A$ & $\% 15 B$ & $\% 15 C$ \\
\hline $\mathrm{SiO}_{2}$ & 17.53 & 16.8 & 17.16 & 17.19 & 16.56 & 17.38 & 17.02 & 16.12 & 16.72 & 16.84 \\
\hline $\mathrm{Al}_{2} \mathrm{O}_{3}$ & 4.73 & 4.53 & 4.55 & 4.58 & 4.42 & 4.55 & 4.52 & 4.31 & 4.4 & 4.5 \\
\hline $\mathrm{Fe}_{2} \mathrm{O}_{3}$ & 2.08 & 1.99 & 2.04 & 2.04 & 1.96 & 1.99 & 2.02 & 1.92 & 1.97 & 1.97 \\
\hline $\mathrm{CaO}$ & 61.87 & 60.84 & 60.99 & 60.87 & 60.26 & 59.15 & 59.83 & 59.61 & 58.94 & 58.53 \\
\hline $\mathrm{MgO}$ & 1.16 & 1.35 & 1.24 & 1.25 & 1.32 & 1.37 & 1.35 & 1.38 & 1.42 & 1.46 \\
\hline $\mathrm{SO}_{3}$ & 3.42 & 3.07 & 3.12 & 3.3 & 2.77 & 2.49 & 2.79 & 2.21 & 2.48 & 2.85 \\
\hline $\mathrm{K}_{2} \mathrm{O}$ & 0.75 & 0.74 & 0.75 & 0.76 & 0.76 & 0.77 & 0.77 & 0.75 & 0.77 & 0.78 \\
\hline $\mathrm{Na}_{2} \mathrm{O}$ & 0.35 & 0.33 & 0.39 & 0.32 & 0.31 & 0.33 & 0.32 & 0.38 & 0.39 & 0.40 \\
\hline LOI & 8.38 & 10.44 & 9.83 & 9.8 & 11.42 & 11.43 & 11.24 & 13.18 & 12.78 & 12.67 \\
\hline \multicolumn{11}{|c|}{ Physical properties } \\
\hline Density $\left[\mathrm{g} / \mathrm{cm}^{3}\right]$ & 3.02 & 2.99 & 2.95 & 3.16 & 2.96 & 2.96 & 2.96 & 2.93 & 2.93 & 2.93 \\
\hline Spreading [mm] & 139 & 130 & 131 & 134 & 133 & 132 & 132 & 129 & 128 & 128 \\
\hline Blaine $\left[\mathrm{cm}^{2} / \mathrm{g}\right]$ & 4435 & & & & & & & & & \\
\hline
\end{tabular}

DTA-TG and FTIR analyses were conducted on $4 \times 4 \times 16-\mathrm{cm}$ specimens of all mixtures after they were exposed to curing of 28, 56 and 98 days. In addition, samples exposed to a 98-day normal curing in water were designated as X-Series. The solution containing $13 \% \mathrm{MgSO}_{4}$ by mass was used to conduct the freezingthawing test, which was performed according to the ASTM C-666 standard. In order to observe the freezing-thawing properties of the cement mixtures that had undergone a 98-day curing process after having been kept in the solution for one week, these cement mixtures were dried to $105^{\circ} \mathrm{C}$ in oven for one week. This process constituted one circle, and four circles were applied to each of the cement mixtures. This method was designated as Y-series. The wetting-drying test was also performed for cement mixtures. In the scope of this test, the cement mixtures were kept in a water curing tank for one week, after which they were removed from the tank and dried in an air-conditioned atmosphere for one week. This process constituted one circle, and four circles were applied to each of the cement mixtures. This method was designated as Z-series.

A capillary absorption test was performed in order to observe the water absorption capacity of the samples with pores. The samples were first dried in an oven at $105{ }^{\circ} \mathrm{C}$ for 24 hours. In order to determine the weight changes, the bottom face of each sample was put into the water at a depth of $0.5 \mathrm{~cm}$. The absorbed water quantities were calculated for each time interval $(2,4$, $8,30,60,120,240$, and 1440 minutes). The weight changes between the dry and wet samples of the cement mixtures ( $X$, $Y$ and $Z$ series) were determined for each cycle from capillary absorption. The weight change calculations were carried out using the following formula:

$W_{D}=\left(W_{t}-W_{0}\right) / W_{0} \cdot 100$

where:
$W_{D}$ - weight change (g)

$W_{t}$ - the weight at $t$ time

$w_{0}$ - initial weight.

\section{Results and discussion}

\subsection{Physical properties}

The density of mortar mixtures is influenced by addition of the RAP. The density of the mixtures involving different RAP percentages and particle sizes is shown in Table 1. The density of the mixtures decreases with an increase in the RAP percentage. This finding can be attributed to the low unit weight of the RAP resulting from low density of RAP mixtures. The Blaine value of the cement amounting to $4435 \mathrm{~cm}^{2} / \mathrm{g}$ is presented in Table 1 .

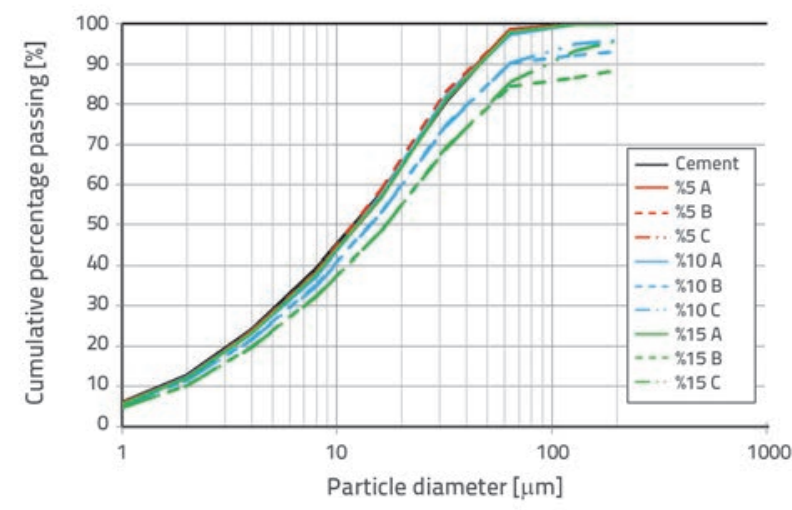

Figure 1. Particle size distributions of the cement mixtures used in the test

The particle size distribution of the mixtures used in the testing is shown in Figure 1. According to the figure, the cement used in the test was finer than other composites. The fineness properties of the 
mixtures varied from A (0.425-2 mm sieve size) to C (0.075-0.180 $\mathrm{mm}$ sieve size) mixtures. Figure 1 also shows that an increase in the amount of the RAP generally decreased fineness of the mixtures. As the cement was finer than the RAP used in the test, the addition of RAP to the mixtures changed fineness of the composites.

\subsection{DTA-TG analysis}

DTA-TG analysis results for the cement and RAP are shown in Figures 2-7.

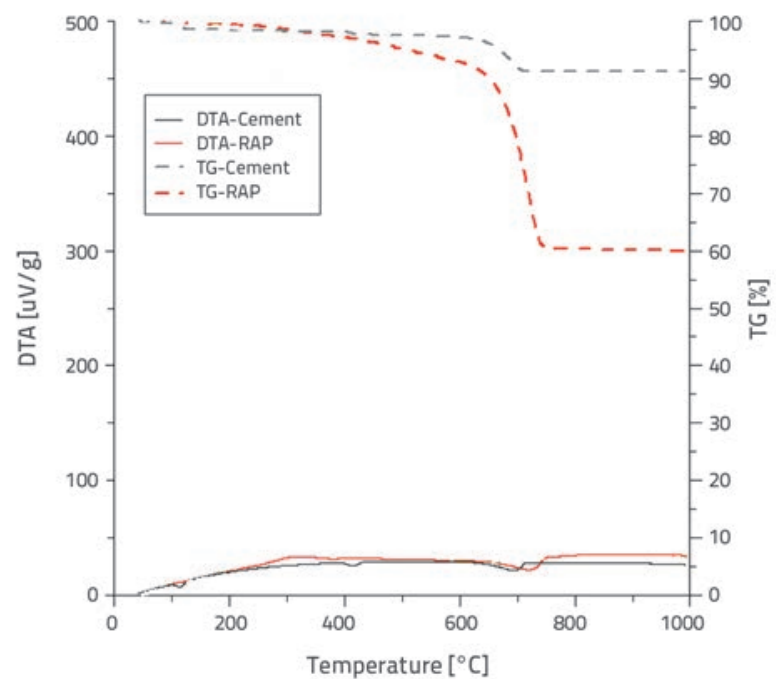

Figure 2. DTA-TG results for raw materials

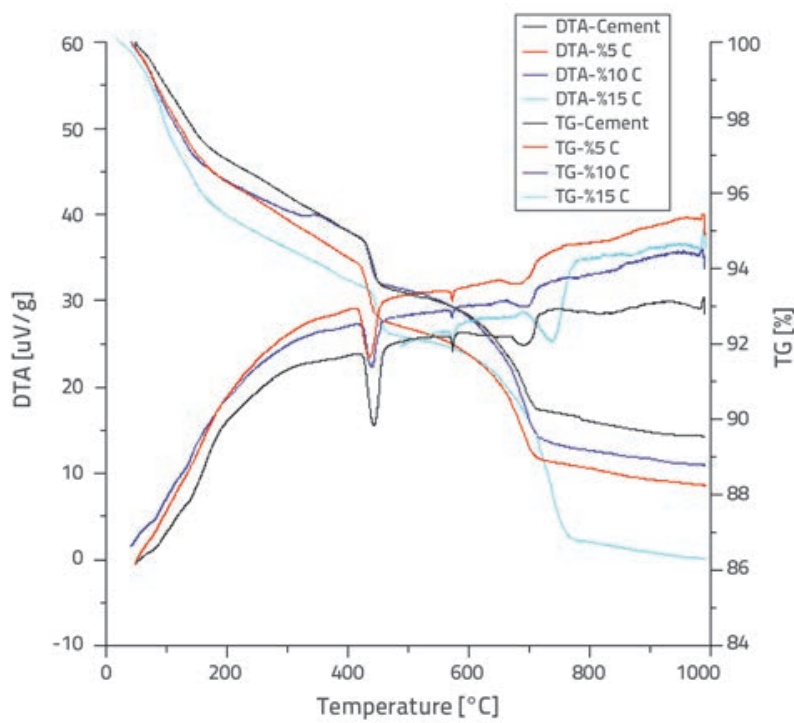

Figure 3. DTA-TG results for 28-day curing time

As shown in Figure 3, the dehydration of the calcium silicate hydrate (CSH) peaks was observed between 100 and $200{ }^{\circ} \mathrm{C}$. The first endothermic peak, registered at 110 ${ }^{\circ} \mathrm{C}$, resulted from the release of the free water of ettringite ( $3 \mathrm{CaO} \cdot \mathrm{Al}_{2} \mathrm{O}_{3} \cdot 3 \mathrm{CaSO}_{4} \cdot 32 \mathrm{H} 2 \mathrm{O}$ ), which overlaps the endothermic effect of the smaller quantity of $\mathrm{CSH}[19,20]$. At the same temperature, $\mathrm{C}_{3} \mathrm{~S}$ and $\mathrm{C}_{2} \mathrm{~S}$ also caused weight losses [20]. As a result of evaluation of other peaks obtained from DTA-TG analyses, and in addition to their endothermic characteristics, the peak registered at $140^{\circ} \mathrm{C}$, the sharp peak in the 420 $470^{\circ} \mathrm{C}$ temperature interval, and a small peak at $575^{\circ} \mathrm{C}$, implies the presence of ettringite, $\mathrm{Ca}(\mathrm{OH})_{2}$, and $\mathrm{C}-\mathrm{S}-\mathrm{H}$, respectively. Similarly, small hump peak at the temperature interval of $680-$ $720^{\circ} \mathrm{C}$ points to the presence of calcite [21-23].

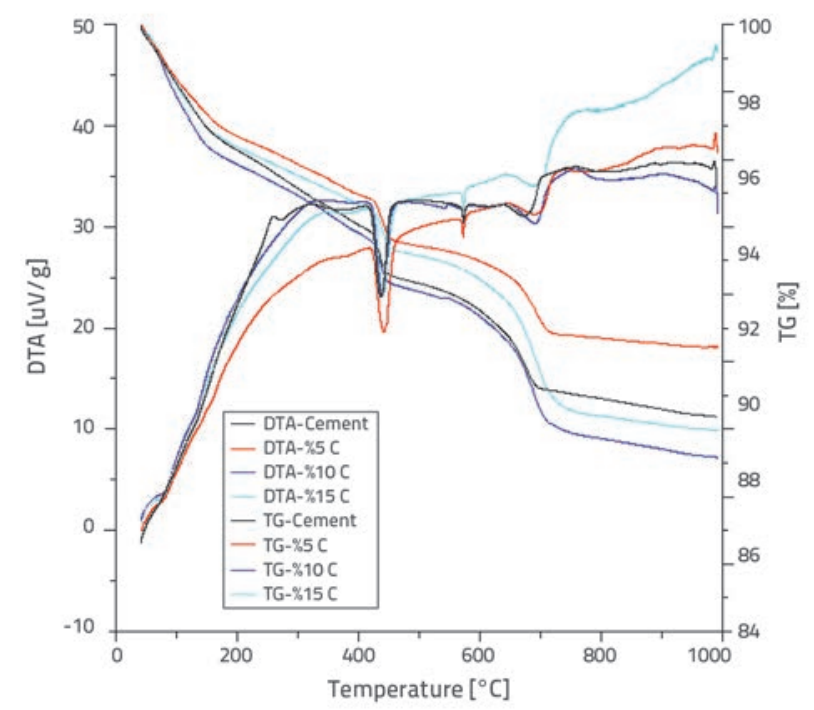

Figure 4. DTA-TG results for 56-day curing time

The quantity of hydration products, such as $\mathrm{CH}$, decreased with an increase in the quantity of RAP. This situation can be explained by the dilution effect and the consumption of $\mathrm{CH}$ via pozzolanic reaction. No significant changes were observed in the dehydration of $\mathrm{CH}$ between the 56- and 28-day of curing. The reduction of dehydration of $\mathrm{CH}$ for the X-Series was, however, registered in all samples. More significant reduction was observed in the $Y$ and $Z$ series samples (Figures 5, 6, 7).

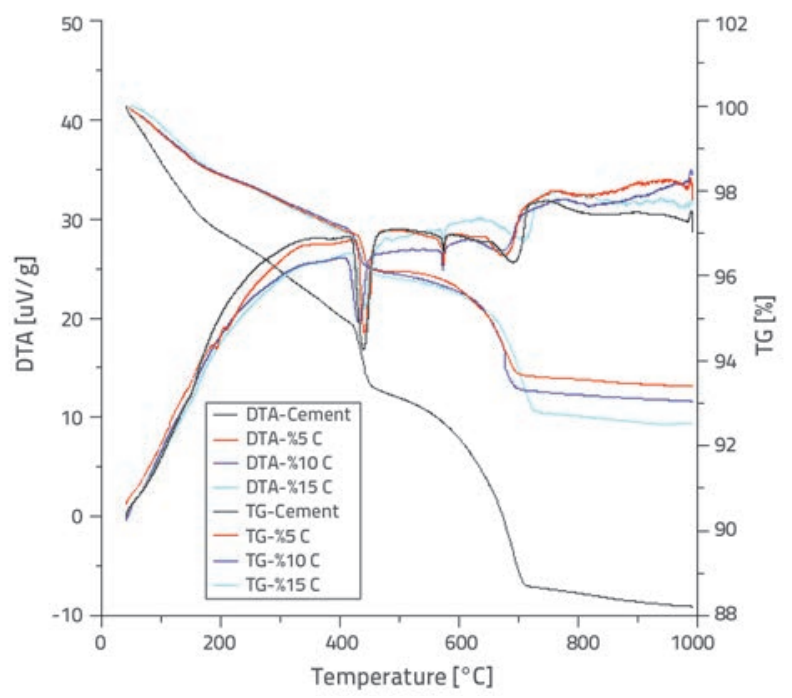

Figure 5. DTA-TG results for 98-day curing time (X-Series) 


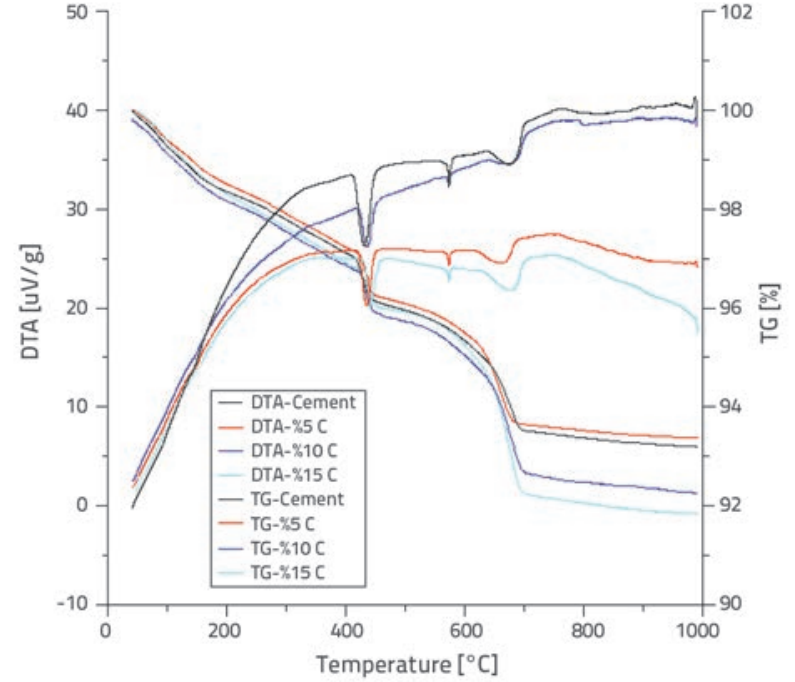

Figure 6. DTA-TG results for 98-day curing time (Y-Series)

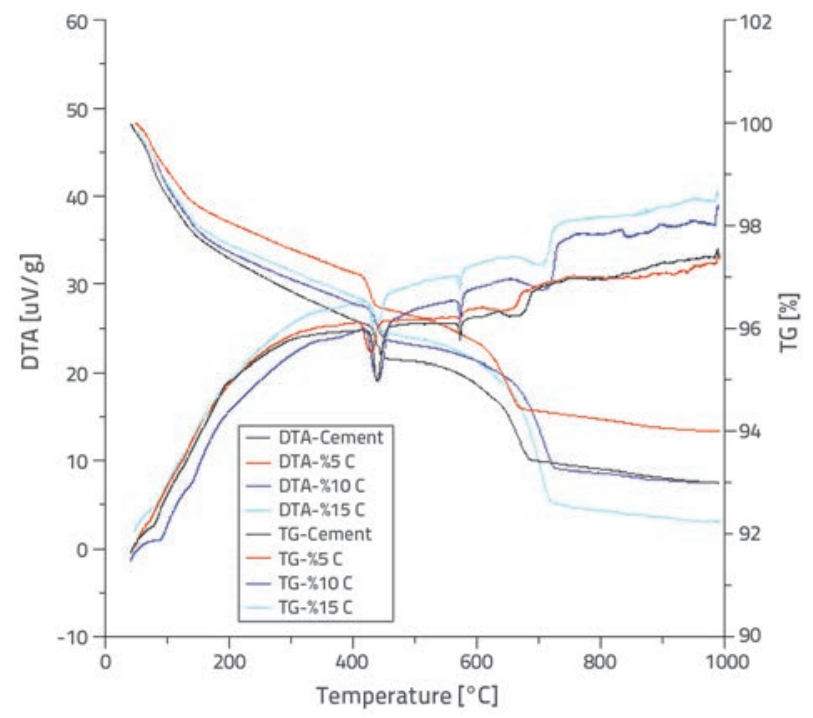

Figure 7. DTA-TG results for 98-day curing time (Z-Series)

The following conclusions can be made based on TG analysis results: It was determined in TG analyses that the mass loss increased with an increase in the quantity of RAP, except in the case of the 28-day curing time. This finding can be explained by the increase in the LOI percent with an increase in the quantity of waste. The highest mass loss of $11.8 \%$ was calculated in the control sample from the $X$ series, which can be attributed to the fact that the control sample had the highest $\mathrm{CaCO}_{3}$ quantity compared to other mixtures. The mass losses from the $5 \%$-, $10 \%-$ and $15 \%$-C series amounted to $6.6 \%, 7 \%$ and $7.5 \%$, respectively. Following evaluation of the mass loss results of the $Y$ series, it was found that the lowest mass loss occurred in the control and $5 \%$-C samples, whose mixture ratios were very close to one another $(6.8 \%, 6.7 \%)$. The other lowest mass losses of $7.7 \%$ and $8.2 \%$ were found in the $10 \%$ - and $15 \%$-C samples, respectively. The mass loss results from the Z group were $6 \%$ for the $5 \%$ addition; $7 \%$ for the control and $10 \%$ addition, and 7.8
$\%$ for the $15 \%$ addition. According to these results, the highest mass losses were determined in the $Y$ group, except in the case of the control sample. This could be explained by harmful effect of the acidic environment. The control sample in the $X$ group had the highest mass loss of all groups, i.e. $11.8 \%$.

\subsection{FTIR analysis}

FTIR analyses were performed to define functional groups of hydration products. Among these groups, the CSH bond regions, which have a direct effect on strength, were examined, and the findings obtained from these analyses were correlated with flexural strength results. Molecular vibrations of the hydration product were determined in the range of $600-4000 \mathrm{~cm}^{-1}$ using FTIR spectroscopy. The FTIR analysis results for cement show vibration peaks at 449, 517, 656, 897, 1080, 1140, 1418, 1615, 3399 and $3615 \mathrm{~cm}^{-1}$. Al-O bonds had a symmetric vibration peak at 449, 517, and $1080 \mathrm{~cm}^{-1}$, while $\mathrm{Si}-\mathrm{O}$ bonds showed symmetric peaks at a wavelength of $897 \mathrm{~cm}^{-1}$. The $\mathrm{SO}_{4}$ bonds formed from plaster in cement were also observed at 656, 1140, and 1615 $\mathrm{cm}^{-1}$. (CO3) $)^{-2}$ was found at $1418 \mathrm{~cm}^{-1}$ [24]. When FTIR peaks were investigated at the compound base, characteristic ettringite bands were observed at 1100 and $610 \mathrm{~cm}^{-1}$ [25]. Characteristic bands of calcite were observed at the values of 2514, 1798, 1421, 874 and $713 \mathrm{~cm}^{-1}$, while quartz peaks were observed in the regions of 619 , $646,693 \mathrm{~cm}^{-1}$. The FTIR and sample hydration results, in terms of peak zone and peak intensity, are shown in Figures 8-9-10. The peaks at $3640 \mathrm{~cm}^{-1}$ were related to water losses of CSH [26]. The peaks at $1460-1420 \mathrm{~cm}^{-1}$ resulted from $\mathrm{CaCO}_{3}$. The peaks related to sulphate were observed in the range of 1090-1150 $\mathrm{cm}^{-1}$, while the peaks in the range of $800-1100 \mathrm{~cm}^{-1}$ were quartz peaks ( $\mathrm{Si}-\mathrm{O})$, which also contributed to the creation of $\mathrm{Al}-\mathrm{O}$ bonds. The peaks at 868 and at $875 \mathrm{~cm}^{-1}$ pointed to the presence of $\mathrm{C}_{2} \mathrm{~S}$ and carbonate, respectively. The peaks located at $1044 \mathrm{~cm}^{-1}$ and $791 \mathrm{~cm}^{-1}$ show Si-O stretching vibrations of $\mathrm{Si}-\mathrm{O}-\mathrm{Si}$ and $\mathrm{Si}-\mathrm{Al}-\mathrm{Si}$, respectively. An $\mathrm{O}-\mathrm{Si}-\mathrm{O}$ bending vibration was determined at $463 \mathrm{~cm}^{-1}$ [27-29].

The peaks at $462 \mathrm{~cm}^{-1}$ were indicative of silicate structure peaks. Curing time and waste additive quantities in samples caused major changes to peak intensity and peak ranges. In some of the samples, it was possible to establish relationships between the peaks and flexural strength of the sample, while no such relations were possible in other cases (Figure 8 to 10).

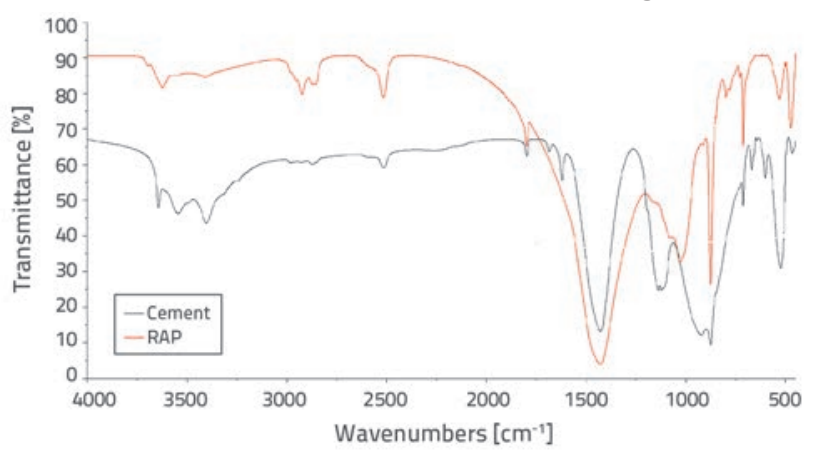

Figure 8. FTIR results for cement and RAP 


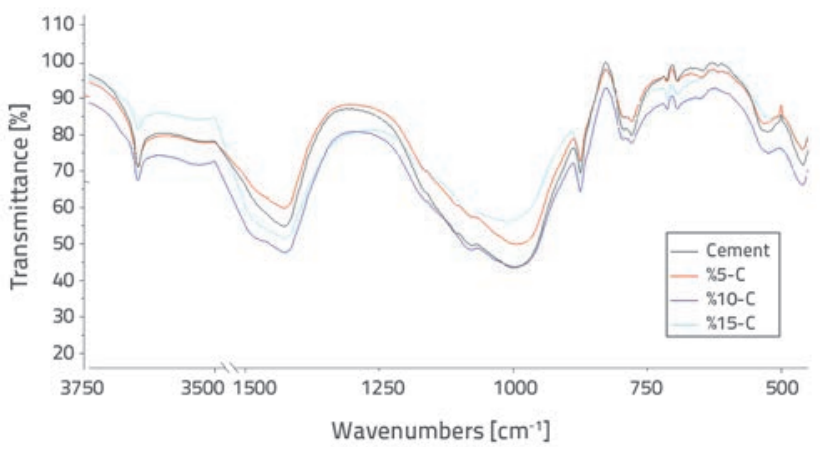

Figure 9. FTIR results for 28-day-curing time

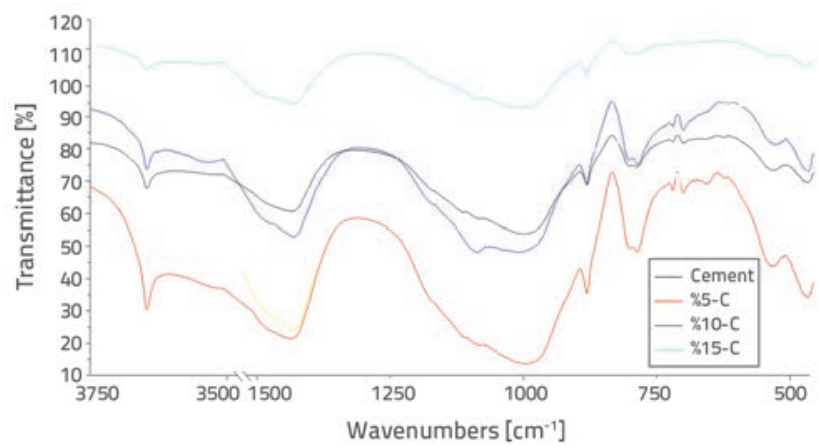

Figure 10. FTIR results for 56-day-curing time

A meaningful correlation between peak intensity and flexural strength was established for the 98-day-curing samples (Figure 11 to 13$)$.

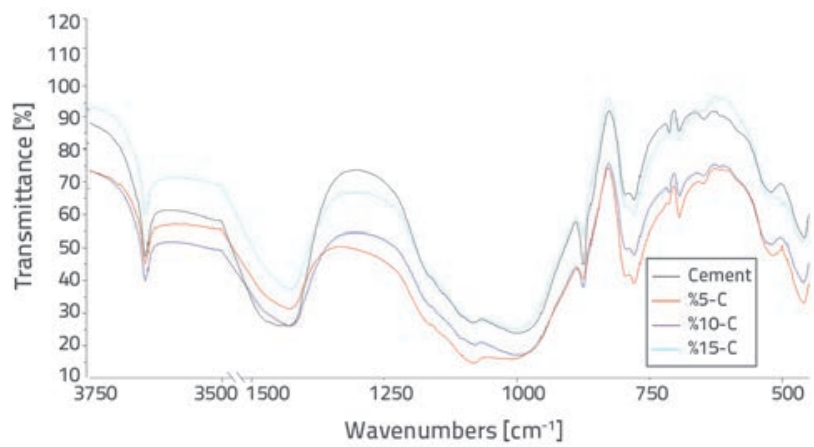

Figure 11. FTIR results for 98-day-curing time (X-Series)

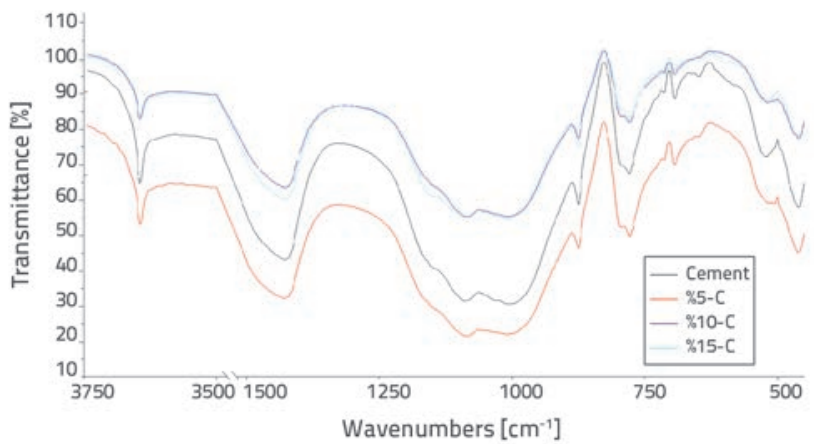

Figure 12. FTIR results for 98-day-curing time (Y-Series)

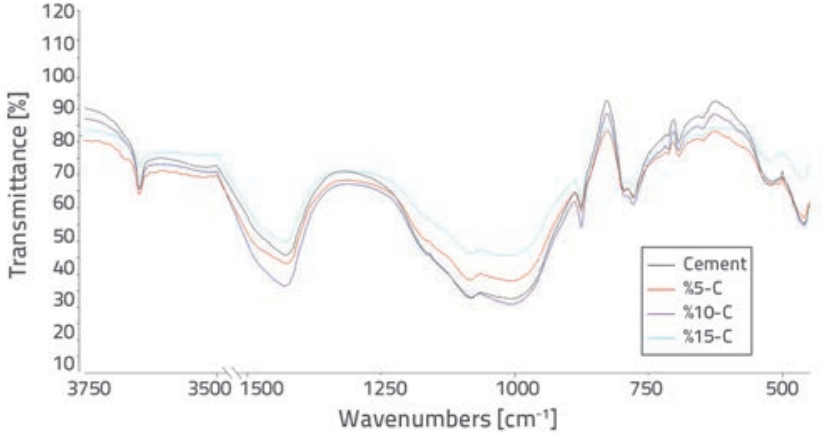

Figure 13. FTIR results for 98-day-curing time (Z-Series)

\subsection{Capillarity test results}

Capillarity test results were obtained for the 28-, 56-, 98day curing periods ( $\mathrm{X}-\mathrm{Y}-\mathrm{Z}$ series) with respect to the mortars produced with the cement mixtures. Capillarity test results for samples after 28-day curing time are shown in Figure 14.

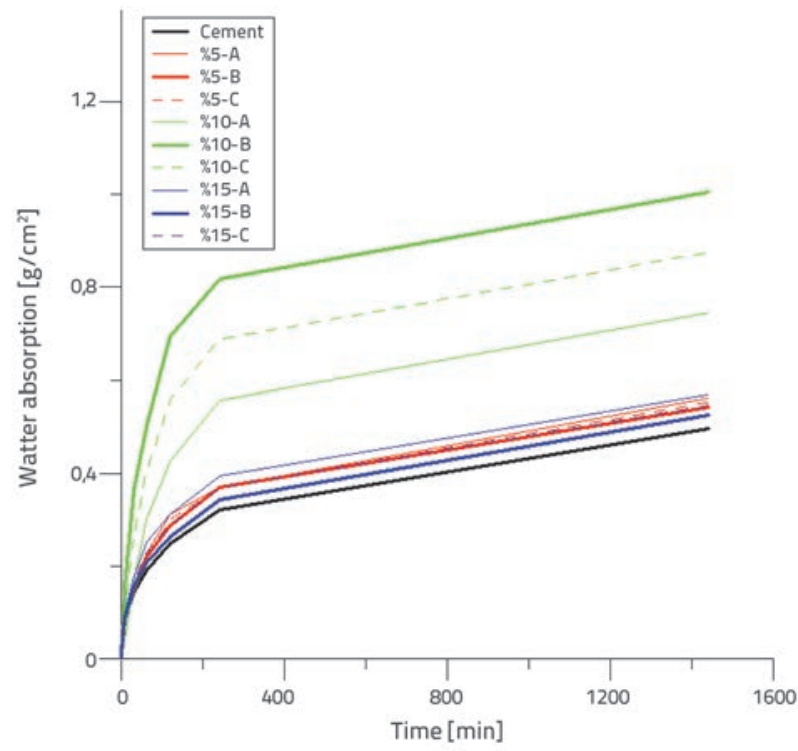

Figure 14. Capillarity test results for $\mathbf{2 8 - d a y - c u r i n g ~ t i m e ~}$

According to Figure 14, capillarity test results of all samples ( $5 \%-C, 10 \%-C, 15 \% C$ ) were generally greater than those of the control sample group. For the same samples, the $10 \%$-B sample mixture showed the largest water absorption ratio. As this series had water surplus, the volume concentration of the capillary pores was greater.

Capillarity test results for 56-day samples are shown in Figure 15. It was observed that the capillarity test results for samples with $10 \%$ RAP are greater than those of control samples. However, the capillarity test results for samples with $5 \%$ RAP were lower than those of control samples. All mixtures prepared with samples at 56-day-curing time provided lower water absorption capacity than the ones with 28-day samples. 


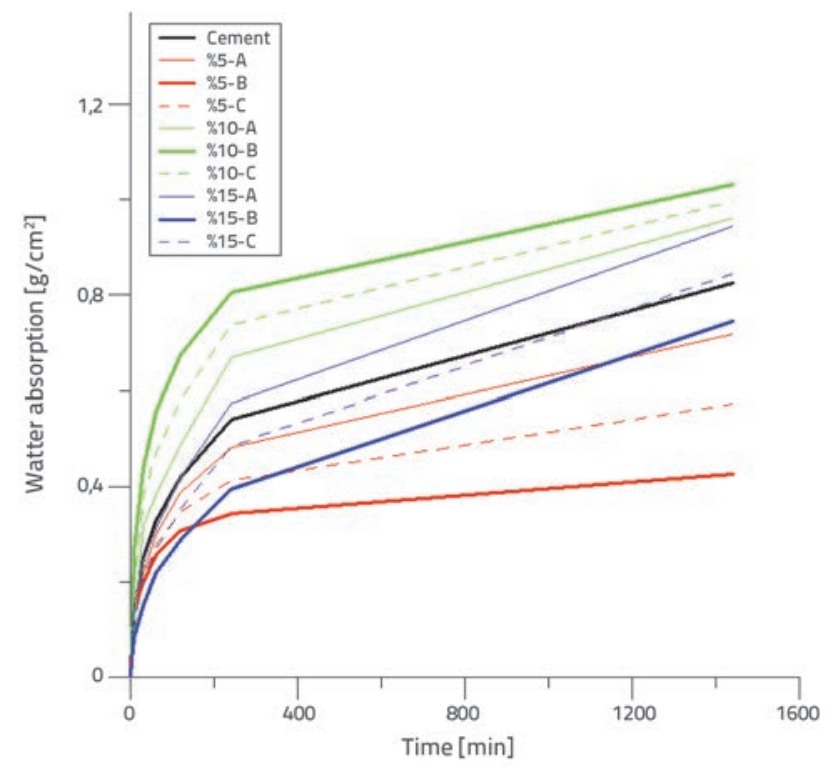

Figure 15. Capillarity test results for 56-day-curing time

Capillarity test results for 98-day samples (X-Series) are given in Figure 16. It can be seen that the water absorption capacity of all samples with $10 \%$ and $15 \%$ RAP content was greater compared to the control sample. The water absorption capacity of samples with $5 \%$ RAP content (except $5 \%$-A) was, however, lower than that of the control sample. All cement mixtures prepared with 98-day samples (X-Series) presented lower water absorption capacities than those produced with 28 - and 56-day samples.

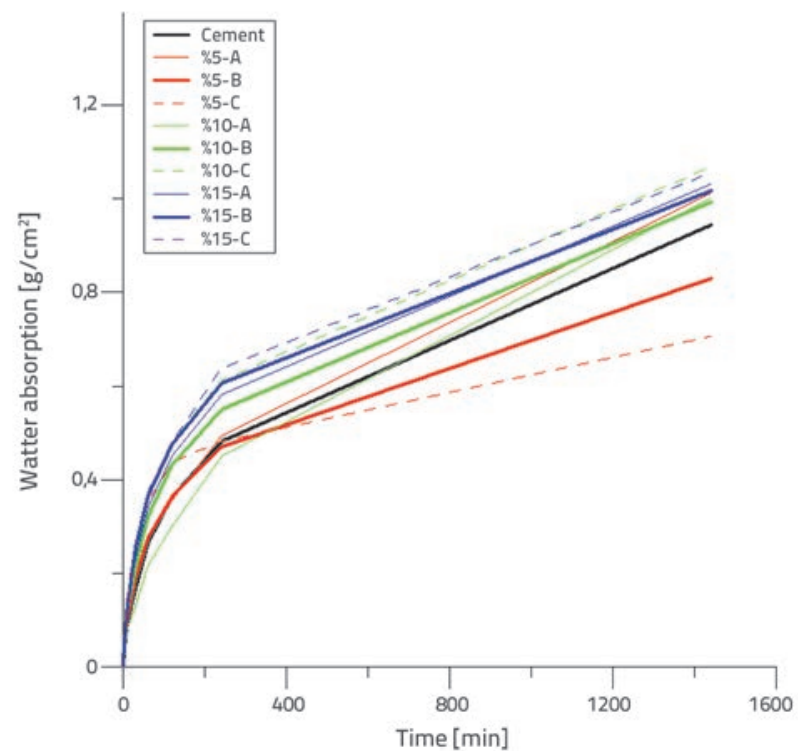

Figure 16. Capillarity test results for 98-day-curing time (X-Series)
Capillarity test results for 98-day samples (Y-Series), which were prepared in a magnesium sulphate solution, are given in Figure 17. The results show that the capillarity test results of all samples in the Y-Series were generally lower than those of the control sample. All curves from the Y-Series showed more notable changes compared to other samples.

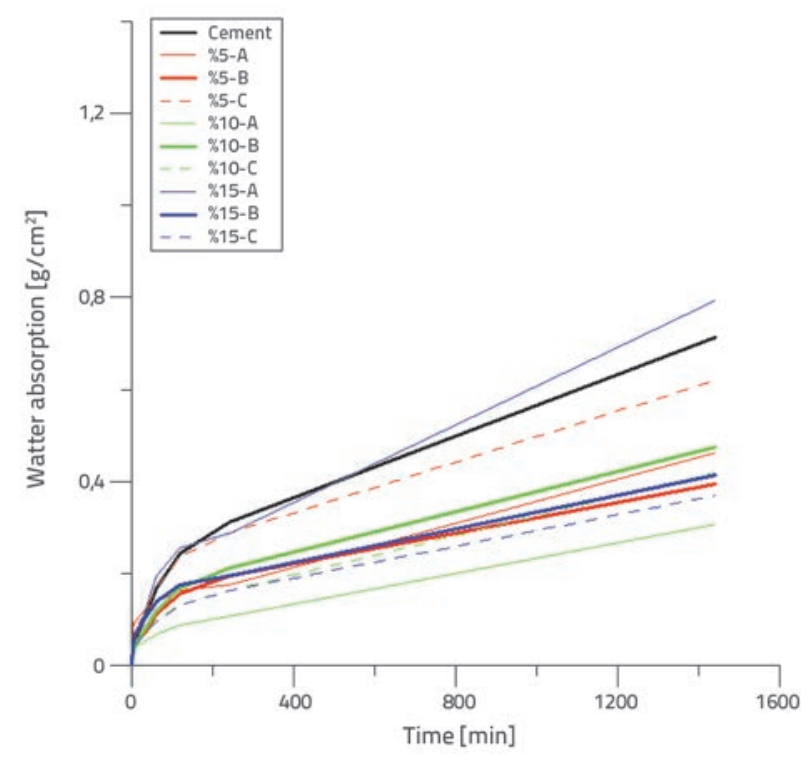

Figure 17. Capillarity test results for 98-day-curing time (Y-Series)

Capillarity test results for 98-day samples (Z-Series), which were prepared utilizing the wetting-drying method, are presented in Figure 18. According to the results shown in the figure, capillarity test results for all samples in the Z-series were generally higher than those of the control sample.

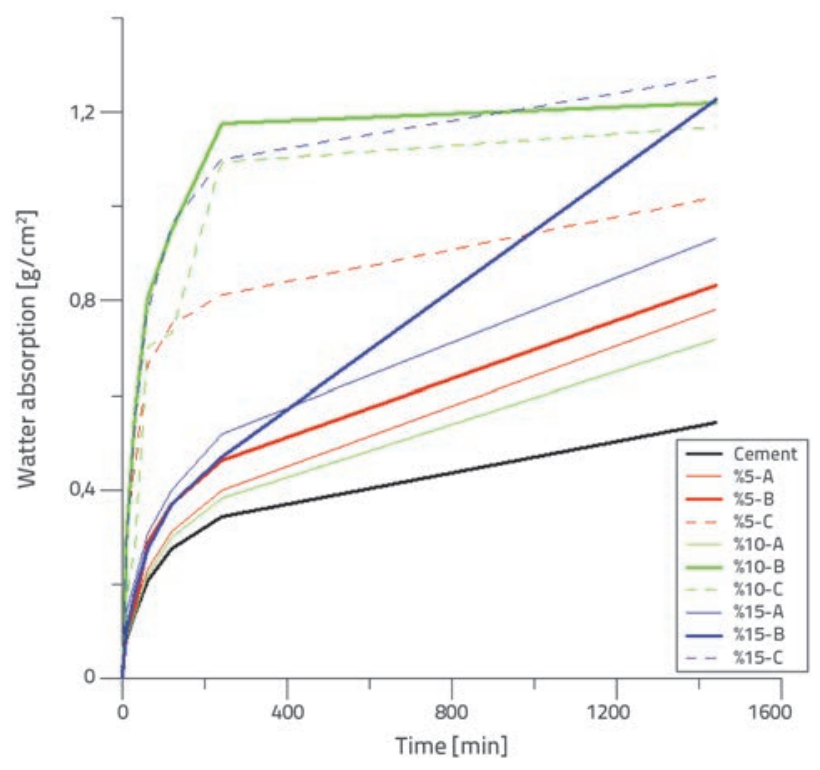

Figure 18. Capillarity test results for 98-day-curing time (Z-Series) 


\subsection{Flexural strength}

Flexural strength tests were carried out on 98-day samples (X-Y-Z series) for the mortars produced with cement mixtures. Flexural strength results for samples belonging to the $X-, Y$ - and Z-series are shown in Figure 19. According to results shown in the figure, the lowest flexural strength value was obtained from the control sample in the $\mathbf{Z}$ series. Two of the values, however, were higher than those in the control sample under $Y$ conditions. The addition of RAP affected positively flexural strength properties of the mixtures in terms of durability, especially for the $Z$ series.

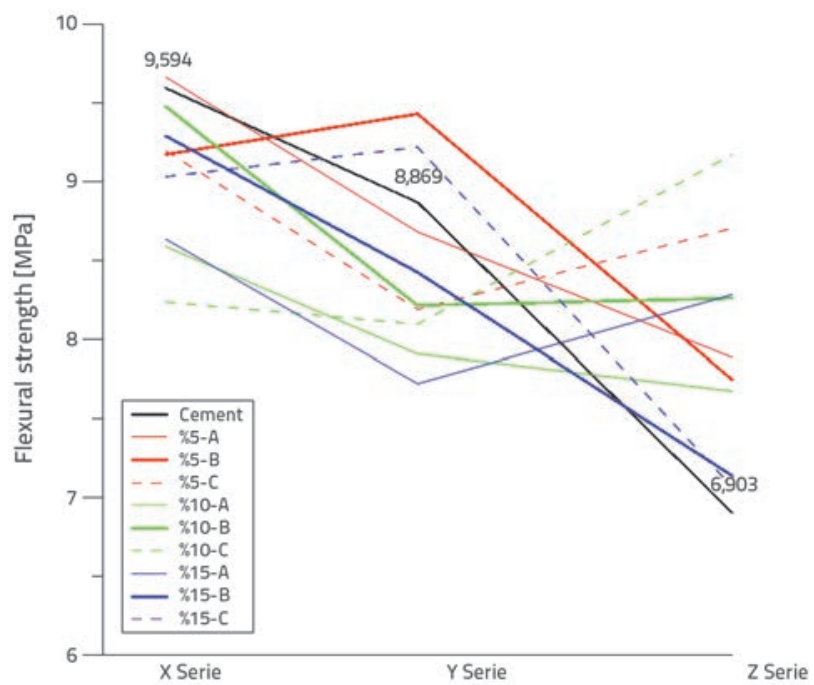

Figure 19. Flexural test results for 98-day-curing time (X,Y,Z-Series)

\subsection{Effects of $X, Y$ and $Z$ curing conditions on results}

DTA-TG results showed reduction of $\mathrm{CH}$ dehydration in all samples under $X$ conditions. The same trend with an increasing trend was seen under $Y$ and $Z$ curing conditions, with the parallel increase in flexural strength. In the $Z$ conditions, flexural strength values of all samples were higher than those of the control sample.

FTIR results were in parallel with the flexural strength values of the $X, Y$ and $Z$ series. Considering the control sample as the reference point, the highest value was obtained from $X$ series and the lowest from $Z$ series, whereas the median value was obtained in the $Y$ series. The same trend was observed for flexural strength.

The flexural strength values of the control sample decreased under $X, Y$ and $Z$ conditions. A decrease was registered in peak results of the control sample under similar conditions. It can therefore be seen that these peaks were directly proportional to the strength values. Although the control sample had a peak similar to that of the $10 \%$ - C under $X$ conditions, the correlation with its flexural strength results could not be established. According to a previous study, the CSH that provides mechanical strength is found in the form of jennite and tobermorite at $1064-$ $1076 \mathrm{~cm}^{-1}, 904-908 \mathrm{~cm}^{-1}$, and $962-970 \mathrm{~cm}^{-1}$ peak intervals [30]. The control sample with the highest flexural strength under $X$ conditions provided a high number of peak areas in these intervals. On the other hand, under $Y$ conditions, the peak areas of the $5 \%$-C sample, which had the highest flexural strength, were the broadest. Examining the same parameter under $Z$ conditions, it was found that the peak was registered in relatively bigger areas in parallel with the $10 \%$-C sample, which had the highest flexural strength.

Regarding capillarity test results under the $X, Y$ and $Z$ curing conditions, the $5 \%$-A and $5 \%$-B added cement mixtures had lower values compared to the control sample under $X$ curing conditions, whereas the best results were obtained under $Y$ conditions. The reason was that the mineral additive clogged the pores and prevented passage of sulphate. The highest capillarity test results were obtained under $Z$ conditions. During the wetting-drying cycles, the structure expands and contracts when it gets wet and becomes dry respectively, which in turn causes stress along particle boundaries.

\section{Conclusion}

Main results derived from the study can be summarized as follows:

- The addition of RAP in cement mixtures influenced density; that is, the density of the cement mixtures decreased with an increase in RAP percentage.

- It was determined that dehydration of $\mathrm{CSH}$ and $\mathrm{CH}$ occurred in the temperature intervals of $110^{\circ} \mathrm{C}, 575^{\circ} \mathrm{C}$ and $420-470$ ${ }^{\circ} \mathrm{C}$, respectively.

- The 28-day DTA results showed that the $5 \%-C$ and 10 $\%$-C samples had lower DTA-peak results than the control sample. However, the $5 \%$-C sample had higher DTA-peak results than the control sample. All findings showed that RAP had a remarkable effect on DTA-TG results in terms of temperature.

- No significant changes were observed in the dehydration of $\mathrm{CH}$ between the 56-day and the 28-day curing time. On the other hand, the reduction in dehydration of $\mathrm{CH}$ for X-series was observed in all samples. This reduction was more notable in the $Y$ and $Z$ series.

- The highest mass loss, i.e. $11.8 \%$ according to TG results, was obtained for the control sample of the $X$ series. Regarding the $X, Y$, and $Z$ groups, the highest mass losses were determined in the $Y$ group.

- According to FTIR analyses, the qualitatively largest areas at the 1064-1076 cm-1, 904-908 $\mathrm{cm}^{-1}$ and 962-970 $\mathrm{cm}^{-1}$ CSH peak intervals were obtained from the samples with the highest flexural strength values, namely, the sample with the addition of $5 \%$ and $10 \%$ of the $X, Y$ and $Z$ series, respectively.

- Capillarity test results of all mortars, save for $15 \%$-A, were lower than those obtained from the $Y$ series control sample at 98 days. Considering these qualitative test results, it can 
be concluded that capillarity was positively affected by the RAP.

- The mixtures including $5 \%$-B and $15 \%$-C could be utilized under $Y$ conditions for flexural strength.

- Accordingly it can be recommended that all cement mixtures examined in this study can be applied to concrete, and that they provide satisfactory flexural strength, since they exhibit superior strength-improving ability compared to the results obtained in the control sample under $Z$ conditions.

\section{REFERENCES}

[1] Zaumanis, M., Mallick, R.B.: Review of very high-content reclaimed asphalt use in plant produced pavements: state of the art., Int. J. Pavement Eng., 34 (2014).

[2] Rinaldini, E., Schuetz, P., Partl, M.N., Tebaldi, G., Poulikakos, D.: Investigating the blending of reclaimed asphalt with virgin materials using rheology, electron microscopy and computer tomography, Composites: Part B., 67 (2014), pp. 579-587, https:// doi.org/10.1016/j.compositesb.2014.07.025

[3] Slanika, T., Madej, T., Jakubekov, D.: DTA contribution to study of hydration fly ash-Portland cement pastes, Thermochim. Acta, 93 (1985), pp. 601, https://doi.org/10.1016/0040-6031(85)85151-0

[4] Monzo, J., Paya, J., Borrachero, M.V., Peris-Mora, E., Velazquez, S.: Fluid catalytic cracking residue (FC3R) as a new pozzolanic material: thermal analysis monitoring of FC3R/Portland cement reactions, in: Proceedings of the Seventh CANMET/ACI International Conference on Fly Ash, Silica Fume, Slag and Natural Pozzolans in Concrete, Supplementary volume, pp. 241, 2001.

[5] Sha, W., Pereira, G.B.: Differential scanning calorimetry study of normal Portland cement paste with $30 \%$ fly ash replacement and of the separate fly ash and ground granulated blast furnace slag powders, in: Proceedings of the Seventh CANMET/ACI International Conference on Fly Ash, Silica Fume, Slag and Natural Pozzolans in Concrete, ACl, Detroit, Supplementary volume, pp. 295, 2001

[6] Justnes, H., Ostnor, T.: Pozzolanic, amorphous silica produced from the mineral olivine, in: Proceedings of the Seventh CANMET/ ACl International ACI Conference on Fly Ash, Silica Fume, Slag and Natural Pozzolans in Concrete-SP-199-44, 2 (2001), pp. 769.

[7] Bhatty, J.I., Dollimire, D., Gamlen, G.A., Mangabhai, R.J., Olmez, H.: Estimation of calcium hydrioxide in OPC, Thermochim. Acta, pp. 106-115, 1986.

[8] Hussain, S.E., Ahmad, S., Al-Gahtani, R.: Corrosion resistance performance of fly ash cement concrete, ACI Mater. J., 91 (1994), pp. 66.

[9] Feldman, R.F., Carette, G.G., Malhotra, V.M.: Mechanisms of hydration reactions in high volume fly ash pastes and mortars, Cem. Concr. Com., 12 (1991), pp. 245, https:/doi. org/10.1016/0958-9465(90)90003-G

[10] Hubbert, C., Wieker, W., Heidemann, D.: Investigations of hydration products in high-volume fly ash binders, in: Proceedings of the Seventh CANMET/ ACI International Conference on Fly Ash, Silica Fume, Slag and Natural Pozzolans in Concrete-SP-199-5, vol. 1, ACl, Detroit, pp. 83, 2001.

\section{Acknowledgements}

The authors extend special thanks to the Istanbul Asphalt Factory, especially to the Head of Production, Zafer Sola, for supplying the waste material. We would also like to gratefully acknowledge the assistance the staff of the Set Cement Factory laboratory provided in the experimental study. This work was supported by the Scientific Research Projects Coordination Unit of Istanbul University, Project number 7681.
[11] Grzybowski, K.F.: Recycled asphalt roofing materials - A multifunctional low cost hot - mix asphalt pavement additive. Use of waste materials in hot-mix asphalt, ASTM STP-1193, 159 (1993), pp. 79.

[12] Button, J.W., Williams, D., Scherocman, J.A.: Roofing shingles and toner in asphalt pavements. Texas Department of Transportation. Report No. FHWA/TX-96/ 1344-2F, 1995.

[13] Foo, K., Hanson, D., Lynn, T.: Evaluation of roofing shingles in hot mix asphalt, Journal of Materials in Civil Engineering, 11 (1999) 1, pp. 15-20

[14] Maupin, W.: Investigation of the use of tear-off shingles in asphalt concrete, Virginia Transportation Research Council. Report no. FHWA/VTRC 10-R23, 2010.

[15] Johnson, E., Johnson, G., Dai, S., Linell, D., McGraw, J., Watson, M.: Incorporation of recycled asphalt shingles in hot mixed asphalt pavement mixtures, Minnesota Department of Transportation. Report no. MN/RC 2010-08, 2010.

[16] Cascione, A.A., Williams, R.C., Buttlar, W.G., Ahmed, S., Hill, B. Haugen, D.S.: Laboratory evaluation of field produced hot mix asphalt containing postconsumer recycled asphalt shingles and fractionated recycled asphalt pavement, Journal of the Association of Asphalt Paving Technologists, 80 (2011), pp. 377-418.

[17] Goh, S.W., You, Z.: Evaluation of recycled asphalt shingles in hot mix asphalt, In: Proceedings of the $1^{\text {st }}$ congress of the transportation and development institute of ASCE; 638 (2011), pp. 45, https://doi. org/10.1061/41167(398)61

[18] European Commission (DG ENV) Final Report Task 2 - Management of construction \& demolition waste, Bio Intelligent Service, 2011.

[19] Ramachandran, V.S., Paroli, R.M., Beaudoin J.J., Delgado, A.H.: Handbook of Thermal Analysis of Contraction Materials, Building Materials Series, William Andrew Publishing, Norwich, New York, U.S.A, 2002.

[20] Ubbriaco, P., Calabrese, D.: Solidification and stabilization of cement paste containing fly ash from municipal solid waste Thermochimicia Acta, 321 (1998), pp. 143-150, https://doi. org/10.1016/S0040-6031(98)00453-5

[21] Taylor, H.W.F.: Cement Chemistry, Second edition,Thomas Telford Services Ltd., 1997, https://doi.org/10.1680/cc.25929

[22] Sha, W.: Differantial scanning calorimetry study of the hydration products in Portland cement pastes with metakaolin replacement, Proceedings of the International Conference on Advances in Building Technology, vol 1, Hong Kong, China, pp. 881-888, 2002. 
[23] Gabrovšek, R., Vuk, T., Kaučič, V.: Evaluation of the hydration of Portland cement containing various carbonates by means of thermal analysis, Acta Chimica Slovenica, 53 (2006), pp.159-165, 2006.

[24] Dorum, A., Koçak, Y., Yılmaz, B., Uçar, A.: Yüksek fııın cürufunun çimento yüzey özelliklerine ve hidratasyona etkileri, Dumlupınar Unv., Journal of Institue of App. Sci., 19 (2009).

[25] Silva, F.G.S., Junior, R.A.F., da Silva, J.S., de Brito, C.M., Andrade, H.M.C., Alves, J.P.G.: Consumption of calcium hydroxide and formation of $\mathrm{C}-\mathrm{S}-\mathrm{H}$ in cement pastes, J Therm Anal Calorim, 116 (2014), pp. 287-293, https://doi.org/10.1007/s10973-0133546-9

[26] Dweck, M., Melchert, M., Viana, F., Cartledge, P., Büchler, P.: Importance of quantitative thermogravimetry on initial cement mass basis to evaluate the hydration of cement pastes and mortar, J Therm Anal Calorim.,113 (2013), pp. 1481-1490, https:// doi.org/10.1007/s10973-013-3112-5
[27] Jahanshahi, R., Akhlaghinia, B.: Expanded perlite:an inexpensive natural efficient heterogeneous catalyst for the green and highly accelerated solvent-free synthesis of 5-substituted-1Htetrazoles using [bmim] $\mathrm{N}_{3}$ and nitriles, RSC Advances, https://doi. org/10.1039/C5RA21481E

[28] Sodeyama, K., Sakka, Y., Kamino, Y.: Preparation of fine expanded perlite, Journal of Material Science, 34 (1999), pp. 2461-2468, https://doi.org/10.1023/A:1004579120164

[29] Majouli, A., Alami Younssi, S., Tahiri, S., Albizane, A., Loukili, H., Belhaj, M.: Characterization of flat membrane support elaborated from local Moroccan Perlite, Desalination, 277 (2011), pp. 61-66, https://doi.org/10.1016/j.desal.2011.04.003

[30] Saez del Bosque, I.F., Martinez-Ramirez, S., Blanco-Varela, M.T. FTIR study of the effect of temperature and nanosilica on the nanostructure of CSH gel formed by hydrating tricalcium silicate, Construction and Building Materials, 52 (2014), pp. 314-323, https://doi.org/10.1016/j.conbuildmat.2013.10.056 